\title{
The function of MMP-28/TGF- $\beta$ induced cell apoptosis in human glioma cells
}

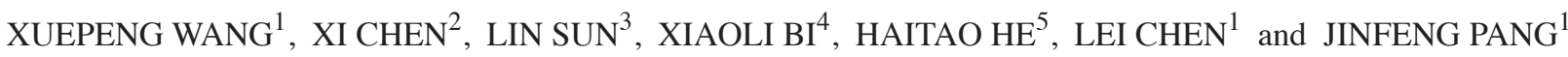 \\ Departments of ${ }^{1}$ Neurosurgery, ${ }^{2}$ Neurology, ${ }^{3}$ Production, ${ }^{4} \mathrm{CT}$ and ${ }^{5}$ Cycle of Internal, \\ Affiliated Hospital of Beihua University, Jilin 132000, P.R. China
}

Received February 15, 2018; Accepted July 2, 2018

DOI: $10.3892 /$ etm.2018.6566

\begin{abstract}
The aim of the present study was to assess the expression status of matrix metalloproteinase (MMP)-28 and to investigate its molecular mechanisms in glioma cells. MicroRNA (miRNA) reverse transcription-quantitative polymerase chain reaction was used to analyze the expression of MMP-28 and transforming growth factor (TGF)- $\beta$ expression in glioma patients and healthy volunteers. MTT and Transwell assays were conducted to determine cell growth and metastasis, respectively. Annexin V/propidium iodide staining was also employed to measure cell apoptosis. MMP-28 and TGF- $\beta$ protein expression were measured using western Blot analysis. The results indicated that MMP-28 and TGF- $\beta$ expression was downregulated in glioma patients, when compared with the normal group. Overall survival and disease-free survival of patients with a low expression of MMP-28 were lower than those with high MMP-28 expression. Overexpression of MMP-28 induced TGF- $\beta$ protein expression, while downregulation of MMP-28 suppressed TGF- $\beta$ protein expression in glioma cell. The downregulation of MMP-28 reduced the cell growth and apoptosis of glioma cell via the suppression of TGF- $\beta$. By contrast, upregulation of MMP-28 induced cell growth and reduced the apoptosis of glioma cells by activating TGF- $\beta$. In addition, the TGF- $\beta$ inhibitor attenuated the effects of MMP-28 in glioma cells. Collectively, the results indicated that MMP-28 was able to induce TGF- $\beta$ in human glioma cells.
\end{abstract}

\section{Introduction}

Glioma is the tumor originating from neuroderm. Glioma shows invasive growth in the brain, and is not well-defined with normal brain tissue (1). Therefore, it can hardly be completely removed surgically. Glioma is not sensitive to chemotherapy

Correspondence to: Mr. Jinfeng Pang, Department of Neurosurgery, Affiliated Hospital of Beihua University, 12 Jiefang Road, Jilin 132000, P.R. China

E-mail: qatgwk5010399@126.com

Key words: glioma cell, transforming growth factor- $\beta$, matrix metalloproteinase-28 or radiotherapy, and is extremely likely to relapse (2). Glioma growing in vital brain sites such as brain stem can hardly be removed surgically (2). On the other hand, drugs like chemical drugs and antitumor Chinese medicine have unsatisfying effect due to the influence of blood brain barrier (3). As a result, glioma remains one of the systemic tumors with the poorest prognosis. New glioma cases in USA from 2009 to 2013 have accounted for $26.9 \%$ of all primary intracranial tumors and $\sim 84 \%$ of all malignant intracranial tumors. Treatment for glioma remains the difficulty in Neurosurgery (4). In addition, the genesis and development mechanism of glioma remains unclear so far (4). Therefore, research on the genesis and development mechanism of glioma, as well as glioma treatment at molecular level, has become the hotspot of research in Neurosurgery field currently (1).

Matrix metalloproteinases (MMPs) are a class of zinc finger metalloprotein family for degrading extracellular matrix proteins. MMPs can change the microenvironment of cell, thus affecting various biological functions of cell (5). They include development, trauma repair, inflammatory response, angiogenesis and pathological processes like periodontitis, arthritis, tumor cell invasion and metastasis. MMP-28 is a new member of the MMP family. It belongs to the MMP-19 subfamily in terms of structure (5). It is first discovered in keratinocyte and testis. In rodent, MMP-28 is expressed in many normal tissues, such as testis, small intestine, skin and lung (6). This indicates that it plays a key role in tissue homeostasis. Researchers find that MMP-28 protein is highly expressed in some tumors compared with that in normal tissue. However, other studies suggest that MMP-28 protein expression is upregulated in malignant tumor and cancer cell lines (6). Marchenko and Strongin (7) showed that MMP-28 is a new human MMP with an unusual cysteine-switch sequence and widely expressed in tumors. However, MMP-28 protein expression is widely expressed in glioma cell, and it is unknown.

Transforming growth factor (TGF)- $\beta$ is highly expressed in multiple tumor tissues, which plays a key role during tumor angiogenesis. Importantly, it is remarkably correlated with tumor genesis, development and metastasis (8). Serum TGF- $\beta$ concentration is notably reduced in patients with glioma after treatment, and tumor invasion capacity is declined (8). Therefore, serum TGF- $\beta$ is regarded to be partially correlated with the prognosis for glioma patients (9). Thus, serum TGF- $\beta$ concentration is partially correlated with the malignant grade 
of tumor (8). Monitoring serum TGF- $\beta$ can evaluate the clinical efficacy, thus displaying certain clinical value for prognosis evaluation (8). This study aims to investigate the expression status of MMP-28 and its molecular mechanisms in glioma cell.

\section{Materials and methods}

Clinical specimens. Serum samples from patients with glioma and healthy volunteers who underwent surgical resection were obtained from the Affiliated Hospital of Beihua University (Jilin, China) between February 2010 and December 2014 (Table I). Serum was stored at $-80^{\circ} \mathrm{C}$ until analysis. The present study was approved by the Ethics Committee of Affiliated Hospital of Beihua University. The study was performed in accordance with the regulations of the Institutional Review Board of Affiliated Hospital of Beihua University. Written informed consent was obtained prior to surgery from all enrolled patients.

RNA extraction and microRNA (miRNA) reverse transcription-quantitative polymerase chain reaction $(R T-q P C R)$. Total RNAs from both serum samples and cells were extracted using TRIzol reagent (Invitrogen; Thermo Fisher Scientific Inc., Waltham, MA, USA). Total RNAs was synthesize complementary DNA using SuperScript II Reverse Transcriptase (Invitrogen; Thermo Fisher Scientific Inc.). RT-qPCR was performed with StepOne Real-Time PCR System (Applied Biosystems, Foster City, CA, USA) and SYBR Premix Ex Taqä (Takara Biotechnology Co., Ltd., Dalian, China). The reaction conditions were pre-denaturation at $95^{\circ} \mathrm{C}$ for $10 \mathrm{~min}$, followed by 40 cycles of denaturation at $95^{\circ} \mathrm{C}$ for $5 \mathrm{~min}$, annealing at $60^{\circ} \mathrm{C}$ for $30 \mathrm{sec}$ and elongation at $72^{\circ} \mathrm{C}$ for $30 \mathrm{sec}$. The relative expression levels were calculated using the $2^{-\Delta \Delta C q}$ method (10).

Cell lines, culture and transfection. The U251 human glioma cell line was purchased from the Cell Bank of Type Culture Collection of Chinese Academy of Sciences (Shanghai, China) and maintained in DMEM (Gibco; Thermo Fisher Scientific, Inc.) supplemented with $10 \%$ fetal bovine serum (FBS; Gibco; Thermo Fisher Scientific, Inc.) and $1 \%$ antibiotic-antimycotic solution at $37^{\circ} \mathrm{C}$ in a humidified $5 \% \mathrm{CO}_{2}$. miRNA-34a, anti-miRNA-34a and negative control mimics were purchased from Shanghai GenePharma Co., Ltd. (Shanghai, China). U251 cells were transfected with miRNA-34a, anti-miRNA-34a and negative control mimics using Lipofectamine 3000 (Invitrogen; Thermo Fisher Scientific, Inc.), according to the manufacturer's protocol.

Cell proliferation assay. The cells $\left(1 \times 10^{4} /\right.$ well) were placed in 96-well plates and transfected with Lipofectamine 2000 (Invitrogen; Thermo Fisher Scientific Inc.). MTT $(20 \mu \mathrm{l})$ was added into each well and incubated for $4 \mathrm{~h}$ at $37^{\circ} \mathrm{C} .150 \mu \mathrm{l}$ isopropanol added and the cells incubated at room temperature in the dark for $20 \mathrm{~min}$. The absorbance was measured using a microplate spectrophotometer (Bio-Tek Instruments Inc., Winosski, VT, USA) at $492 \mathrm{~nm}$.

Transwell assay. Cells $\left(2 \times 10^{4}\right.$ cells) were seeded into the upper chambers of Transwell chambers (Corning Inc., Corning, NY, USA) and $500 \mu \mathrm{l}$ DMEM supplemented with $10 \%$ FBS
Table I. Characteristics of glioma patients and healthy volunteers.

\begin{tabular}{lcc}
\hline Variables & Patients (n=82) & $\begin{array}{c}\text { Healthy } \\
\text { volunteers }(\mathrm{n}=42)\end{array}$ \\
\hline $\begin{array}{l}\text { Age (years) } \\
\quad 55\end{array}$ & & \\
$>55$ & 40 & 19 \\
Sex & 42 & 23 \\
$\quad$ Female & 35 & \\
$\quad$ Male & 47 & 17 \\
Tumor size (cm) & & 25 \\
$\quad \leq 3.0$ & 15 & $n / \mathrm{a}$ \\
$>3.0$ & 67 & $\mathrm{n} / \mathrm{a}$ \\
Edmondson grade & & \\
I & 7 & $\mathrm{n} / \mathrm{a}$ \\
II & 13 & $\mathrm{n} / \mathrm{a}$ \\
III-IV & 62 & $\mathrm{n} / \mathrm{a}$ \\
\hline
\end{tabular}

$\mathrm{n} / \mathrm{a}$, not applicable.

was added into the lower wells as the chemo-attractant. After cultivation for $48 \mathrm{~h}$, the filters were stained with crystal violet.

Cell apoptosis assay. Cell was washed with PBS and harvested at $1,000 \mathrm{~g}$ for $10 \mathrm{~min}$ at room temperature. Cell was stained with Annexin V (allophycocyanin) and propidiumiodide for $15 \mathrm{~min}$ at room temperature in the dark. Apoptosis rate was acquired with a fluorescence-activated cell sorting Canto II flow cytometer (BD Biosciences, San Jose, CA, USA) and analyzed using Flowjo 7.6.1 (FlowJo, LLC, Ashland, OR, USA).

Western blot analysis. Cellular nuclear protein was extracted using PIRA assay and the protein concentration was detected using a BCA kit (Beyotime Institute of Biotechnology, Haimen, China). $50 \mu \mathrm{g}$ of protein were separated using $10 \%$ SDS-PAGE gel and transferred onto PVDF membranes (EMD Millipore, Billerica, MA, USA). Membranes were blocked with 5\% skim milk in TBST for $2 \mathrm{~h}$ at room temperature, and incubated with primary antibodies MMP-28, TGF- $\beta$ and GAPDH overnight at $4^{\circ} \mathrm{C}$. Membranes were washed with TBST for $15 \mathrm{~min}$ and incubated with corresponding horseradish peroxidase-conjugated secondary antibodies (Beyotime Institute of Biotechnology; 1:1,000 dilution) for $1 \mathrm{~h}$ at room temperature. Membranes were visualized using a Millipore Enhanced Chemiluminescence system and analyzed using Image Lab 3.0 (Bio-Rad Laboratories, Inc., Hercules, CA, USA).

Immunofluorescence. Cells were washed with PBS and fixed in $4 \%$ paraformaldehyde at $4^{\circ} \mathrm{C}$ for $15 \mathrm{~min}$ at room temperature. Cells were blocked with 5\% BSA and 0.25 Triton X-100 for $1 \mathrm{~h}$. Cells were incubated with TGF- $\beta$ at $4^{\circ} \mathrm{C}$ overnight. Cells were washed with PBST, 555-secondary antibodies (HRP conjugated, PerkinElmer, Inc., Waltham, MA, USA) were used for $1 \mathrm{~h}$ at $37^{\circ} \mathrm{C}$. Cells were stained with DAPI assay for $15 \mathrm{~min}$ 

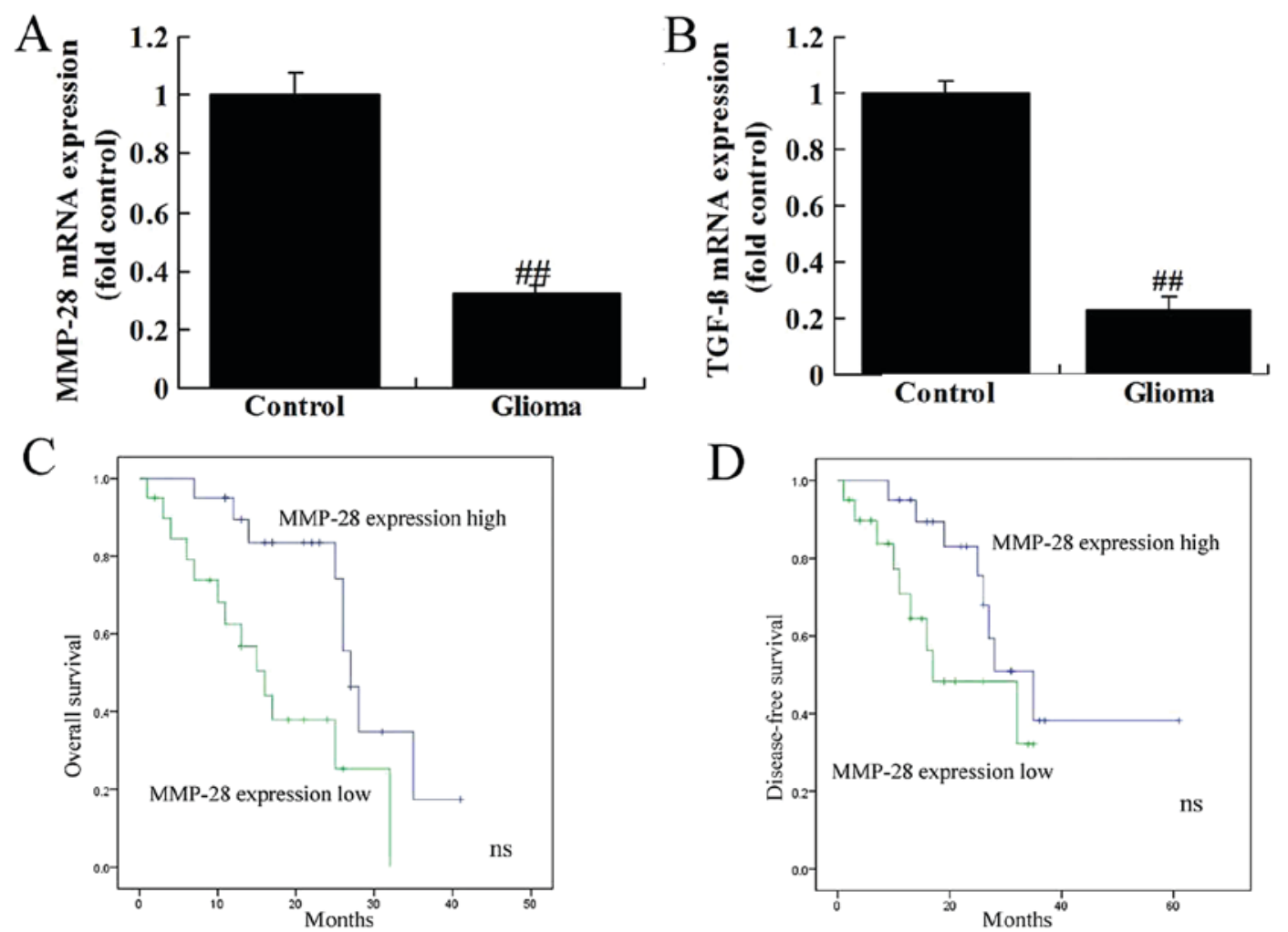

Figure 1. MMP-28 and TGF- $\beta$ expression in glioma patients. (A) MMP-28 miRNA expression, (B) TGF- $\beta$ mRNA expression, and the (C) OS and (D) DFS of MMP-28. ${ }^{\# \#} \mathrm{P}<0.01$ vs. control group. Control, healthy volunteer group; Glioma, glioma group. MMP, matrix metalloproteinase; TGF- $\beta$, transforming growth factor- $\beta$; OS, overall survival; DFS, disease-free survival.

at darkness and washed with PBST for 15 min. Laser scanning confocal microscopy (Leica Microsystems GmbH, Wetzlar, Germany) was used for cell observation.

Statistical analysis. The data were expressed as the mean \pm standard deviation, and were analyzed using SPSS 17.0 software (SPSS, Inc., Chicago, IL, USA). The differences between different groups were compared using Student t-tests or one-way analysis of variance and Tukey's post hoc test. $\mathrm{P}<0.05$ was considered to indicate a statistically significant difference.

\section{Results}

MMP-28 and TGF- $\beta$ expression in glioma patients. The mRNA expression of MMP-28 and TGF- $\beta$ was reduced in glioma patients, compared normal group (Fig. 1A and B). Overall survival (OS) and disease-free survival (DFS) of patients with low MMP-28 expression were lower than those with low MMP-28 expression (Fig. 1C and D).

MMP-28 regulated TGF- $\beta$ protein expression in glioma cell. Further, we investigated whether MMP-28 regulated TGF- $\beta$ protein expression in glioma cell. As shown in Fig. 2A-F, over-expression of MMP-28 induced TGF- $\beta$ protein expression, while downregulation of MMP-28 suppressed TGF- $\beta$ protein expression in glioma cell, compared with control group. In addition, immunofluorescence showed that over-expression of MMP-28 induced TGF- $\beta$ protein expression in glioma cell, in comparison with control group (Fig. 2G).
Upregulation of MMP-28 reduced cell growth of glioma cell. To examine the function of MMP-28 on cell growth of glioma cell, MMP-28 expression was upregulated in glioma cell. Consequently, upregulation of MMP-28 induced cell growth and metastasis, and reduced apoptosis and caspase-3/9 activity level in glioma cell, compared with control group (Fig. 3).

Downregulation of MMP-28 induced cell growth of glioma cell. To further determine the function of MMP-28 on cell growth of glioma cell, si-MMP-28 was used to transfect glioma cell. As a result, downregulation of MMP-28 reduced cell growth and metastasis, and induced apoptosis and caspase-3/9 activity level in glioma cell, in comparison with control group (Fig. 4).

TGF- $\beta$ inhibitor attenuated the effects of MMP-28 in glioma cell. To confirm the function of TGF- $\beta$ in the effects of MMP-28 in glioma cell, $0.5 \mu \mathrm{M}$ of ITD-1, inhibitor of TGF- $\beta$, was used in this study. As shown in Fig. $5 \mathrm{~A}$ and B, TGF- $\beta$ inhibitor suppressed TGF- $\beta$ protein expression in glioma cell by MMP-28, compared with MMP-28 group. In addition, TGF- $\beta$ inhibitor attenuated the effects of MMP-28 on cell growth and metastasis, and apoptosis and caspase-3/9 activity level in glioma cell (Fig. 5C-J).

\section{Discussion}

Glioma is characteristic of high invasion, high recurrence rate and high mortality. The major cause of high glioma-induced mortality can be attributed to its high invasion. Glioma is invasive and ill-defined with the normal brain tissue (3). Therefore, 


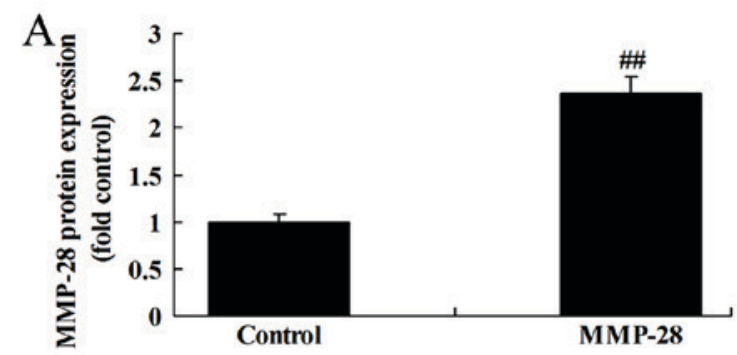

$\mathrm{C}$
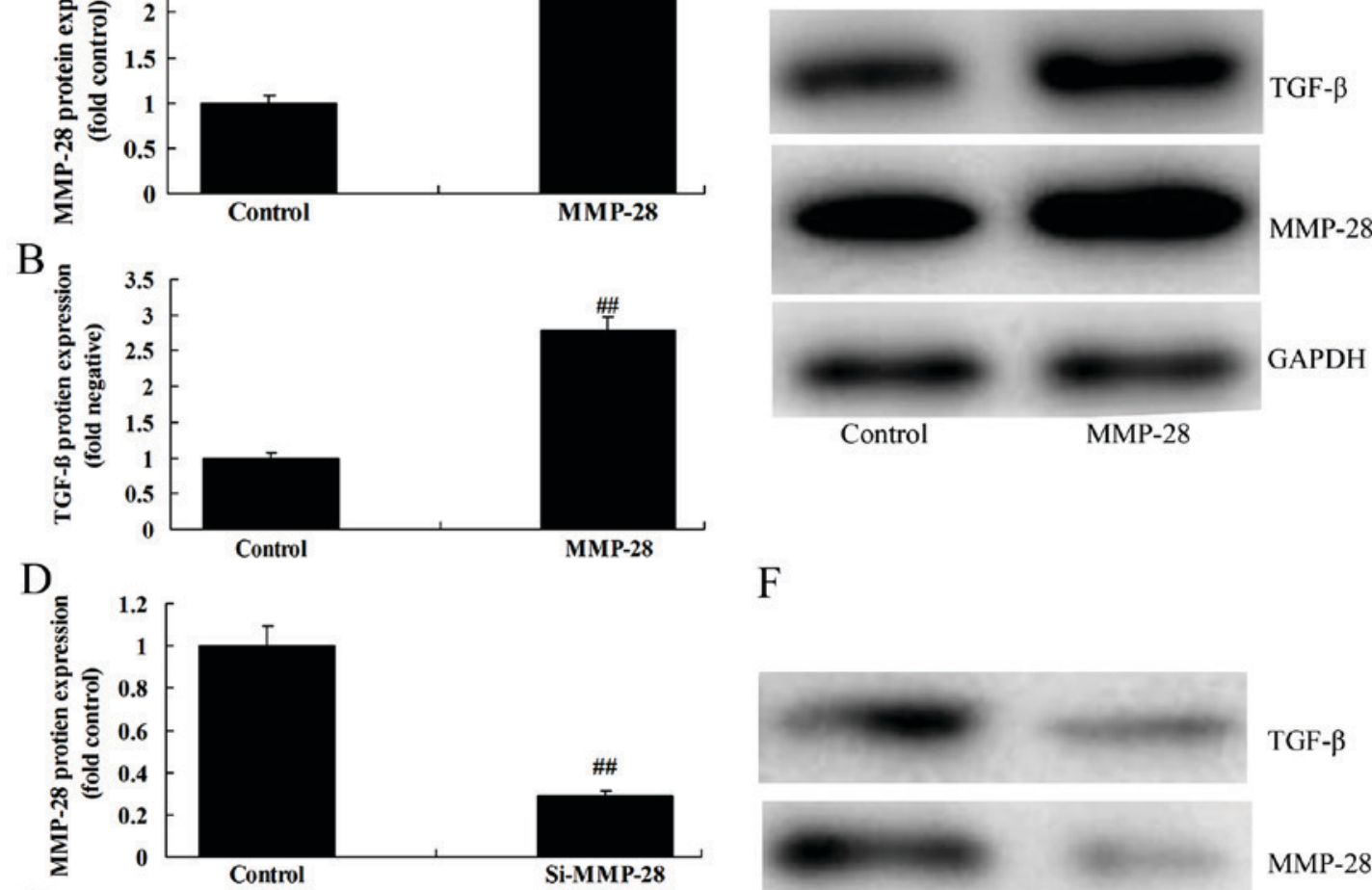

$\mathrm{F}$
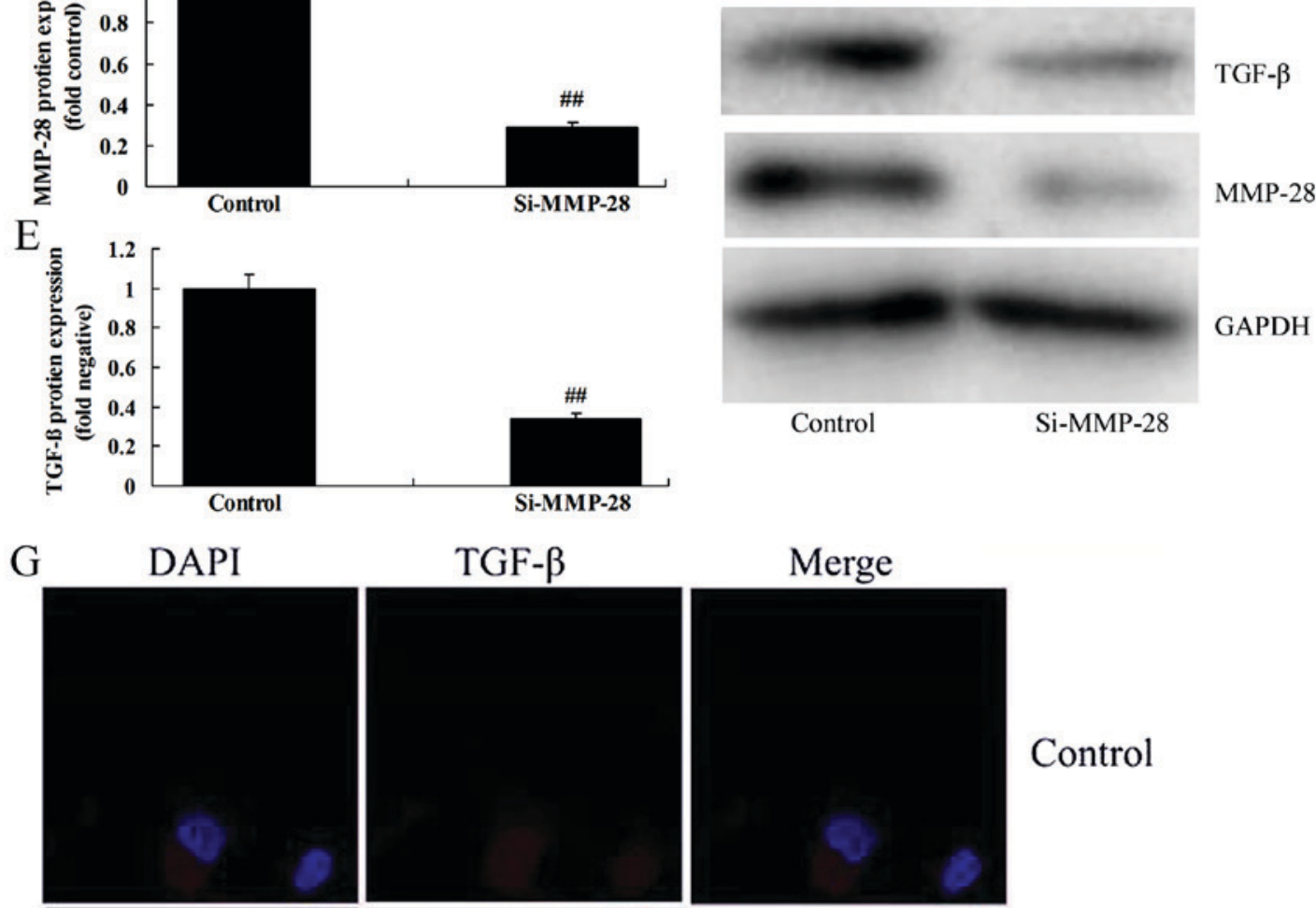

\section{Control}
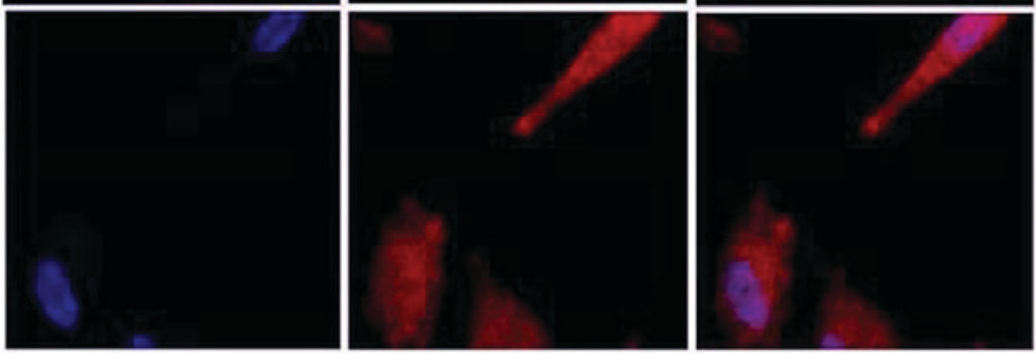

MMP-28

Figure 2. MMP-28 regulates TGF- $\beta$ protein expression in glioma cell. (A) MMP-28 and (B) TGF- $\beta$ protein expression was determined by (C) western blot analysis following the overexpression of MMP-28 expression. (D) MMP-28 and (E) TGF- $\beta$ protein expression was also determined by (F) western blot analysis following the downregulation of MMP-28 expression. (G) Immunofluorescence for MMP-9 protein expression (magnification, $\mathrm{x} 400$ ). ${ }^{\# \#} \mathrm{P}<0.01 \mathrm{vs}$. control group. Control, negative control group; MMP, matrix metalloproteinase; MMP-28, overexpression of MMP-28 group; Si-MMP-28, downregulation of MMP-28 group using small interfering RNA; TGF- $\beta$, transforming growth factor- $\beta$.

it can hardly be completely removed surgically. Moreover, glioma growing in vital sites like brain stem cannot even be treated surgically (3). Glioma is not sensitive to radiotherapy or chemotherapy, and is extremely likely to relapse. Therefore, 

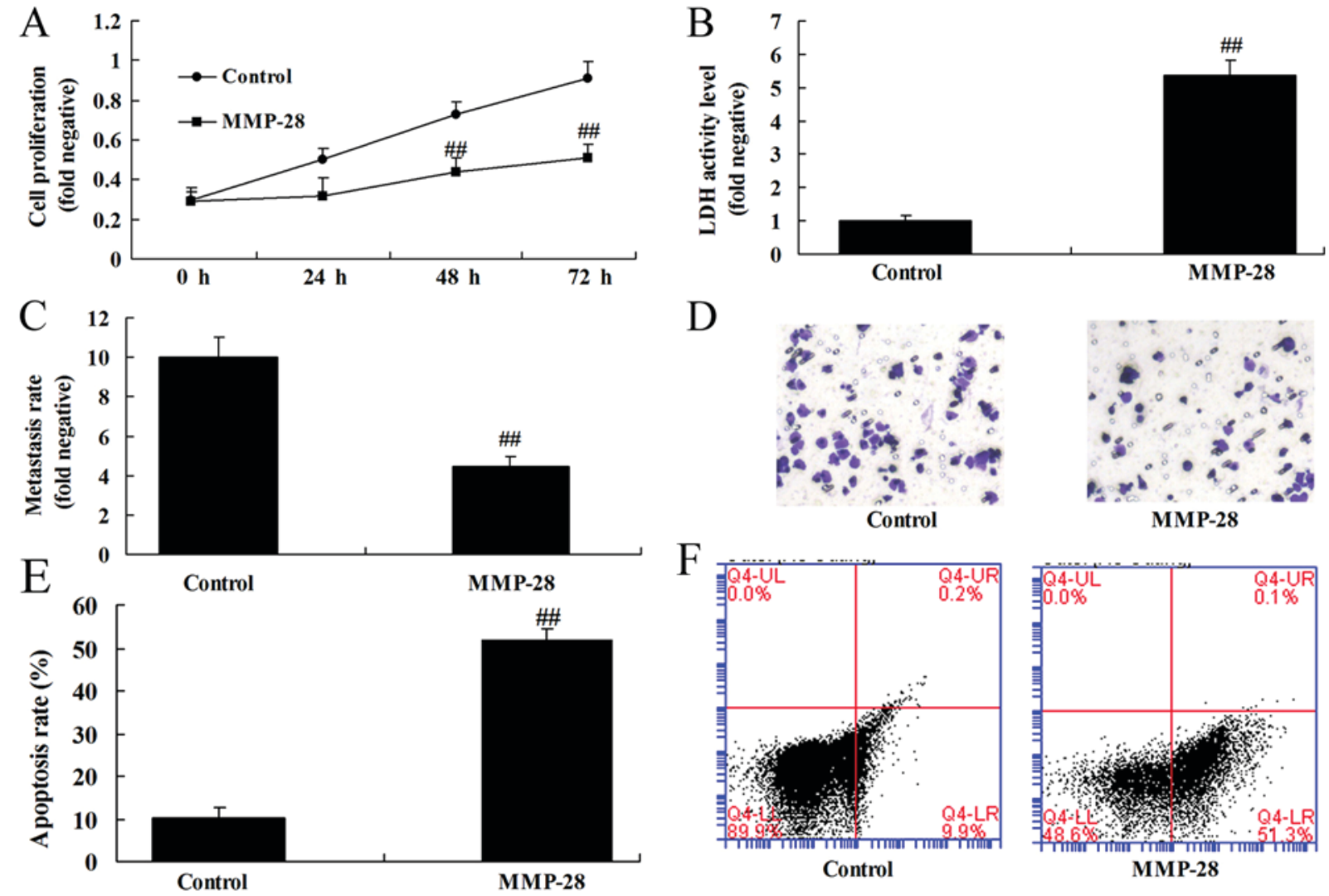

$\mathrm{D}$

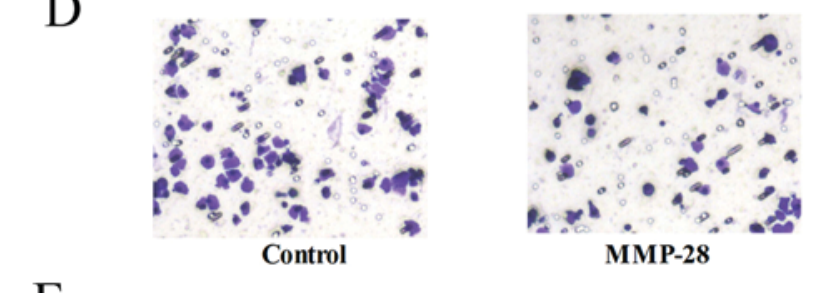

$\mathrm{F}$
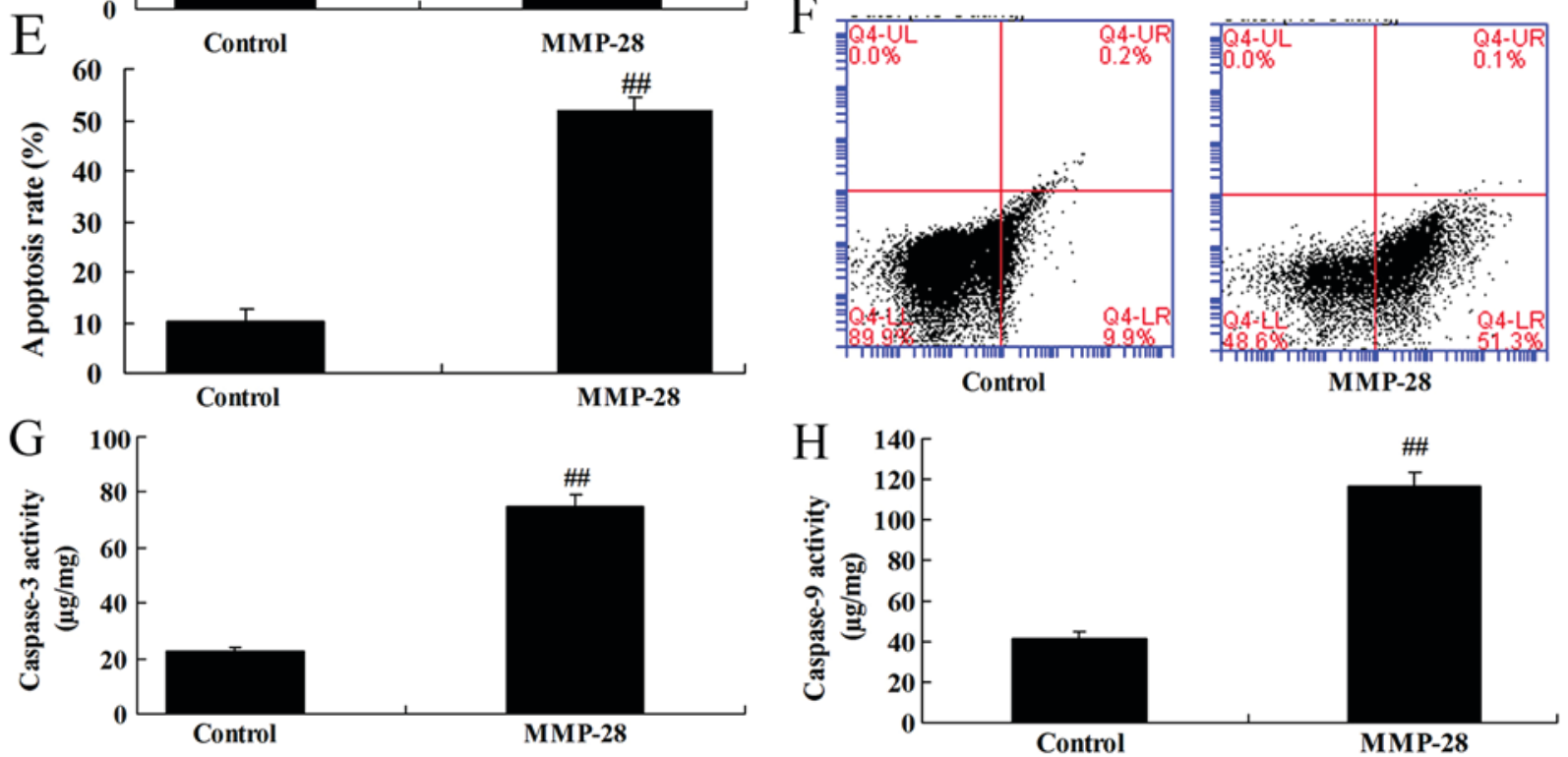

Figure 3. Upregulation of MMP-28 reduces glioma cell growth. (A) Cell growth; (B) LDH activity level; and (C and D) migration rate (magnification, $x 10$ ). (E) Apoptotic rate was determined by (F) flow cytometry; and (G) caspase-3 and (H) caspase-9 activity was measured. ${ }^{\# \prime} \mathrm{P}<0.01$ vs. control group. Control, negative control group; MMP, matrix metalloproteinase; MMP-28, overexpression of MMP-28 group; LDH, lactate dehydrogenase.

glioma patients are associated with low survival rate (3). The results demonstrated that MMP-28 and TGF- $\beta$ mRNA expression were reduced in glioma patients. OS and DFS of MMP-28 expression low were lower than those of MMP-28 expression low group. These results showed that MMP-28 participated in the genesis and development of glioma patients. In this study, we only used one cell line U251 cell, which is astrocytoma line and an insufficient present study, and we will use more cell model in further study.

The MMPs family is constituted by 23 structurally correlated enzymes, which can reconstruct and degrade the extracellular matrix (5). At the same time, they can act on the non-extracellular matrix components to promote the release of soluble factors, such as growth factor and extracellular matrix cytokines (7). Numerous studies suggest that, under physiological conditions, MMP-28 plays a vital role in embryogenesis and trauma healing (7). Pathological conditions, such as tumor growth and metastasis, destruction of arthritic cartilage and cardiovascular diseases, are also related to MMPs (11).
MMP-28 is highly expressed in skin basal cell and keratinocyte in upper basement, as well as in the developing spermatogonium in testis and lung (7). MMP-28 expression is relatively high in lung, heart, rectum, small intestine and brain at protein level. In the injured skin, MMP-28 expression in mitotic cell at the edge of wound is upregulated (11). However, in keratinocyte with migration capacity, MMP-28 expression is not upregulated (11). MMP-28 is also related to the immune function because it is expressed in normal circulatory $\mathrm{T}$ cell. Moreover, its expression quantity is increased in cartilage in the case of osteoarthritis. MMP-28 has different expression profiles in different tumors (12). Typically, MMP-28 expression is downregulated during the formation of colorectal cancer (13). This indicates that MMP-28 plays a key role in maintaining homeostasis of cell. In addition, research finds that, in oral squamous cell carcinoma, MMP-28 knockdown will delay cell growth (12). In lung adenocarcinoma, high MMP-28 expression can activate the potential TGF $\beta$ pathway. Thus, it can induce the epithelial-mesenchymal transition (EMT) of epithelial cell (14). These results demonstrated that 

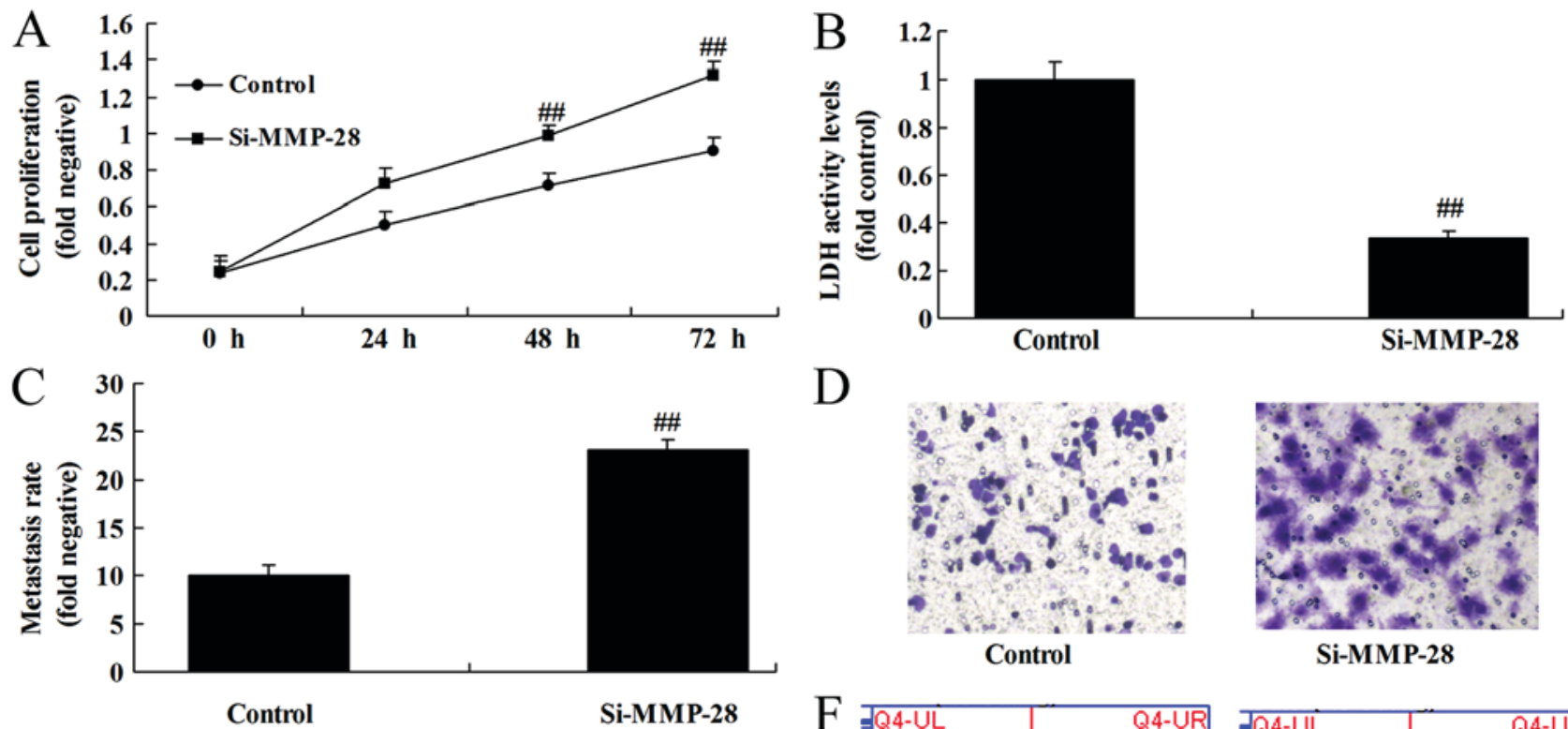

$\mathrm{D}$
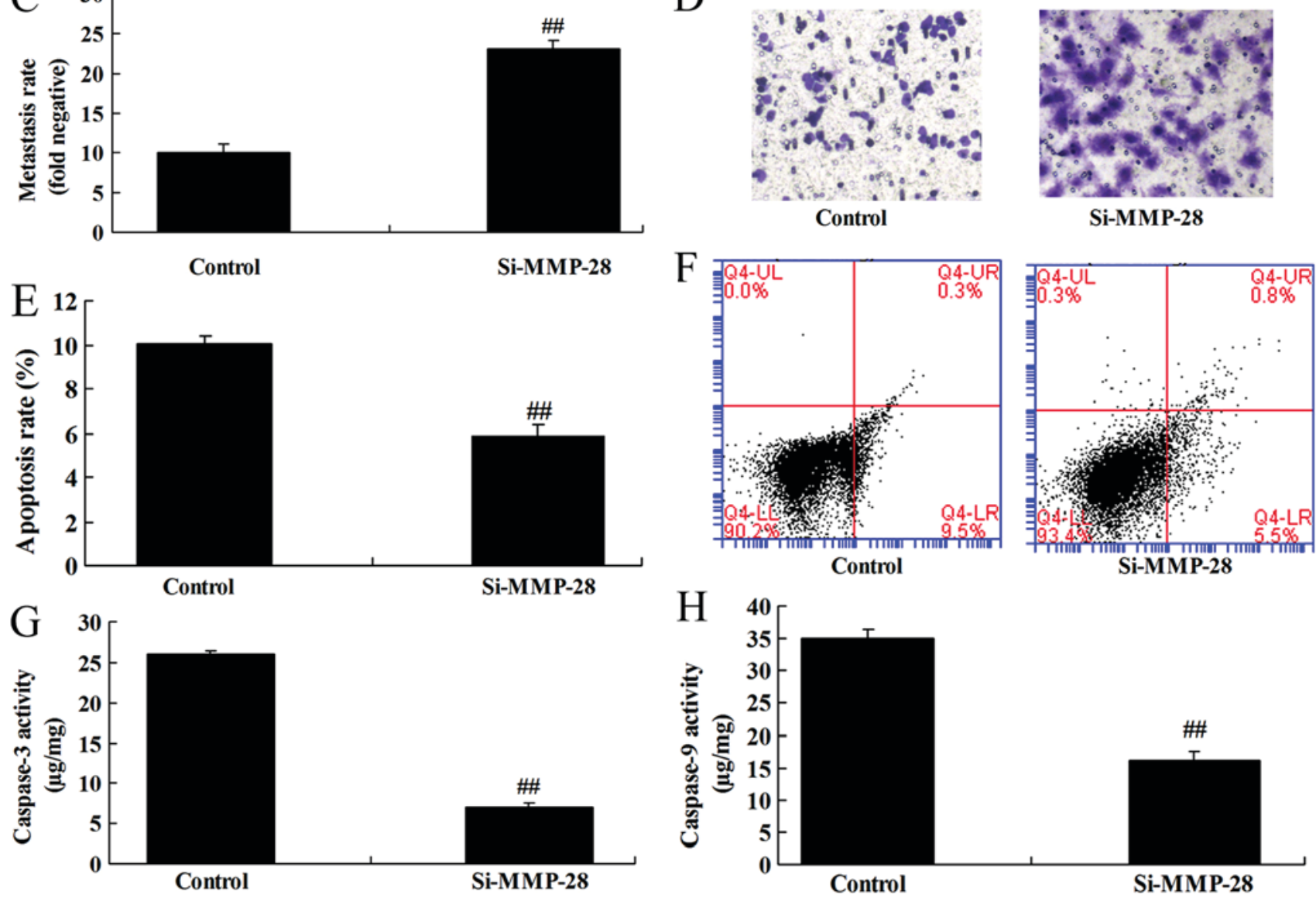

Figure 4. Downregulation of MMP-28 induces glioma cell growth. (A) Cell growth; (B) LDH activity level; and (C and D) migration rate (magnification, x10). (E) Apoptotic rate was determined by (F) flow cytometry; and (G) caspase-3 and (H) caspase-9 activity was measured. ${ }^{\#} \mathrm{P}<0.01$ vs. control group. Control, negative control group; MMP, matrix metalloproteinase; Si-MMP-28, downregulation of MMP-28 group using small interfering RNA; LDH, lactate dehydrogenase.

over-expression of MMP-28 induced TGF- $\beta$ protein expression in glioma cell. Illman et al (14) suggested that MMP-28 regulates TGF- $\beta$ in malignant cells. These results were similar to our results, and indicated that MMP-28 regulates TGF- $\beta$ in glioma cell and malignant cells.

The role of MMP-28 in regulating the effect of $\beta$-catenin on the TGF- $\beta 1$-induced EMT of human lung adenocarcinoma cell line A549 is observed. Such irreversible transition manifests in the following aspects (15). Firstly, expression, mutation and deletion of cell surface E-cadherin are reduced. Secondly, TGF- $\beta$ complex protein is depolymerized (16). Thirdly, active TGF- $\beta$ level is increased. The TGF- $\beta$ activity in the above cascade events inducing the initiation of EMT can be neutralized by MMPs inhibitor GM6001 or its antibody (17). However, the blocking effect cannot reverse the cell phenotype once the EMT begins. Experiment indicates that, MMP-28 can induce EMT genesis and cell invasion through the TGF- $\beta$-dependent mechanism (16). This reveals that such enzyme participates in regulating epithelial cell function and mediating tumor genesis (15). This study indicated that TGF- $\beta$ inhibitor inhibited the effects of MMP-28 in glioma cell. Illman et al (15) reported that MMP-28 induces TGF- $\beta$ mediated epithelial to mesenchymal transition in lung carcinoma cells.

In conclusion, our study firstly demonstrated that MMP-28 and TGF- $\beta$ expression were inhibited in glioma patients. Moreover, our results showed that the function of MMP-28 in human glioma cell to induces TGF- $\beta$, which may provide a novel insight into tumorigenesis and the basis for the development of MMP-28/TGF- $\beta$-targeting therapies against glioma. 


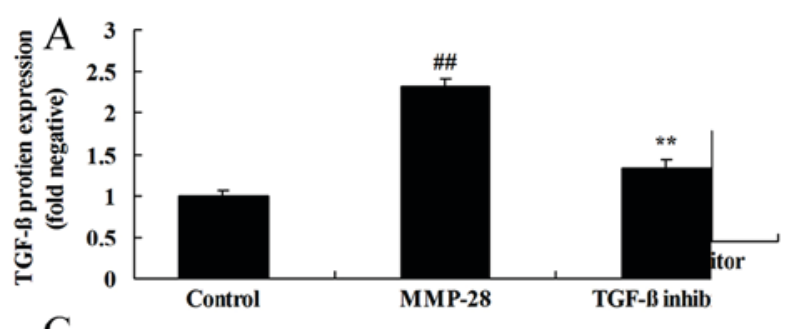

$\mathrm{B}$
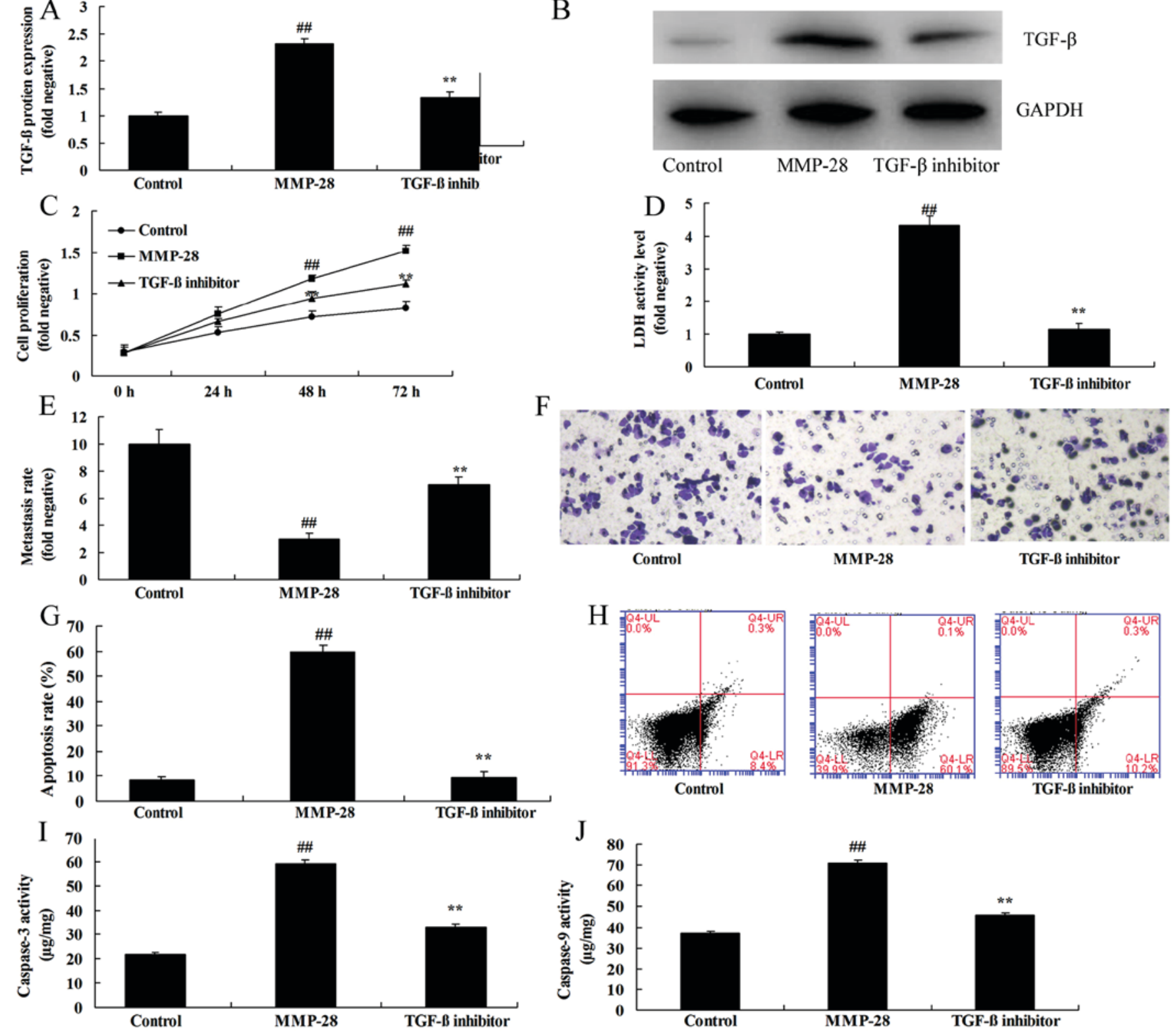

Figure 5. TGF- $\beta$ inhibitor inhibits the effects of MMP-28 in glioma cells. (A) TGF- $\beta$ protein expression was determined using (B) western blot analysis. (C) Cell growth, (D) LDH activity level, (E and F) migration rate (magnification, x10), (G) apoptotic rate, which was determined using (H) flow cytometry, and (I) caspase-3 and (J) caspase-9 activity were also measured. ${ }^{\# *} \mathrm{P}<0.01$ vs. control group; ${ }^{* *} \mathrm{P}<0.01$ vs. MMP-28 group. Control, negative control group; MMP, matrix metalloproteinase; MMP-28, overexpression of MMP-28 group; TGF- $\beta$, transforming growth factor- $\beta$; TGF- $\beta$ inhibitor, overexpression of MMP-28 and TGF- $\beta$ inhibitor group.

\section{Acknowledgements}

Not applicable.

\section{Funding}

The present study was supported by funds from the Education Department of Jilin Province (grant no. JJKH20170056KJ).

\section{Availability of data and materials}

The analyzed datasets generated during the current study are available from the corresponding author on reasonable request.

\section{Authors' contributions}

JP designed the experiments. XW, XC, LS, XB, HH and LC performed the experiments. JP and XW analyzed the data, and JP wrote the manuscript.

\section{Ethics approval and consent to participate}

The present study was approved by the Ethics Committee of the Affiliated Hospital of Beihua University. The study was performed in accordance with the regulations of the Institutional Review Board of Affiliated Hospital of Beihua University. Written informed consent was obtained prior to surgery from all enrolled patients. 


\section{Patient consent for publication}

Written informed consent was obtained prior to surgery from all enrolled patients.

\section{Competing interests}

The authors declare that they have no competing interests.

\section{References}

1. Weller M, Butowski N, Tran DD, Recht LD, Lim M, Hirte H, Ashby L, Mechtler L, Goldlust SA, Iwamoto F, et al: Rindopepimut with temozolomide for patients with newly diagnosed, EGFRvIII-expressing glioblastoma (ACT IV): A randomised, double-blind, international phase 3 trial. Lancet Oncol 18: 1373-1385, 2017.

2. Blumenthal DT, Rankin C, Stelzer KJ, Spence AM, Sloan AE, Moore DF Jr, Padula GD, Schulman SB, Wade ML and Rushing EJ: A Phase III study of radiation therapy (RT) and $\mathrm{O}^{6}$-benzylguanine $+\mathrm{BCNU}$ versus $\mathrm{RT}$ and $\mathrm{BCNU}$ alone and methylation status in newly diagnosed glioblastoma and gliosarcoma: Southwest Oncology Group (SWOG) study S0001. Int J Clin Oncol 20: 650-658, 2015.

3. Pollack IF, Jakacki RI, Butterfield LH, Hamilton RL, Panigrahy A, Potter DM, Connelly AK, Dibridge SA, Whiteside TL and Okada H: Antigen-specific immune responses and clinical outcome after vaccination with glioma-associated antigen peptides and polyinosinic-polycytidylic acid stabilized by lysine and carboxymethylcellulose in children with newly diagnosed malignant brainstem and nonbrainstem gliomas. J Clin Oncol 32: 2050-2058, 2014.

4. Eisenstat DD, Pollack IF, Demers A, Sapp MV, Lambert P, Weisfeld-Adams JD, Burger PC, Gilles F, Davis RL, Packer R, et al: Impact of tumor location and pathological discordance on survival of children with midline high-grade gliomas treated on Children's Cancer Group high-grade glioma study CCG-945. J Neurooncol 121: 573-581, 2015.

5. Yan H, Wang W, Dou C, Tian F and Qi S: Securin promotes migration and invasion via matrix metalloproteinases in glioma cells. Oncol Lett 9: 2895-2901, 2015.

6. Bister VO, Salmela MT, Karjalainen-Lindsberg ML, Uria J, Lohi J, Puolakkainen P, Lopez-Otin C and Saarialho-Kere U: Differential expression of three matrix metalloproteinases, MMP-19, MMP-26, and MMP-28, in normal and inflamed intestine and colon cancer. Dig Dis Sci 49: 653-661, 2004.
7. Marchenko GN and Strongin AY: MMP-28, a new human matrix metalloproteinase with an unusual cysteine-switch sequence is widely expressed in tumors. Gene 265: 87-93, 2001.

8. Pan YB, Zhang CH, Wang SQ, Ai PH, Chen K, Zhu L, Sun ZL and Feng DF: Transforming growth factor beta induced (TGFBI) is a potential signature gene for mesenchymal subtype high-grade glioma. J Neurooncol 137: 395-407, 2018.

9. Guo Z, Li G, Bian E, Ma CC, Wan J and Zhao B: TGF- $\beta$-mediated repression of MST1 by DNMT1 promotes glioma malignancy. Biomed Pharmacother 94: 774-780, 2017.

10. Livak KJ and Schmittgen TD: Analysis of relative gene expression data using real-time quantitative PCR and the 2(-Delta Delta $\mathrm{C}(\mathrm{T})$ ) method. Methods 25: 402-408, 2001.

11. Suomela S, Koljonen V, Skoog T, Kukko H, Böhling T and Saarialho-Kere U: Expression of MMP-10, MMP-21, MMP-26, and MMP-28 in Merkel cell carcinoma. Virchows Arch 455: 495-503, 2009.

12. Gencer S, Cebeci A and Irmak-Yazicioglu MB: Matrix metalloproteinase gene expressions might be oxidative stress targets in gastric cancer cell lines. Chin J Cancer Res 25: 322-333, 2013.

13. Manicone AM, Gharib SA, Gong KQ, Eddy WE, Long ME, Frevert CW, Altemeier WA, Parks WC and Houghton AM: Matrix metalloproteinase-28 is a key contributor to emphysema pathogenesis. Am J Pathol 187: 1288-1300, 2017.

14. Illman SA, Lohi J and Keski-Oja J: Epilysin (MMP-28)-structure, expression and potential functions. Exp Dermatol 17: 897-907, 2008.

15. Illman SA, Lehti K, Keski-Oja J and Lohi J: Epilysin (MMP-28) induces TGF-beta mediated epithelial to mesenchymal transition in lung carcinoma cells. J Cell Sci 119: 3856-3865, 2006.

16. Rao S, Zaidi S, Banerjee J, Jogunoori W, Sebastian R, Mishra B, Nguyen BN, Wu RC, White J, Deng C, et al: Transforming growth factor- $\beta$ in liver cancer stem cells and regeneration. Hepatol Commun 1: 477-493, 2017.

17. Åström P,Juurikka K, Hadler-Olsen ES, Svineng G, Cervigne NK, Coletta RD, Risteli J, Kauppila JH, Skarp S, Kuttner S, et al: The interplay of matrix metalloproteinase-8, transforming growth factor- $\beta 1$ and vascular endothelial growth factor- $\mathrm{C}$ cooperatively contributes to the aggressiveness of oral tongue squamous cell carcinoma. Br J Cancer 117: 1007-1016, 2017.

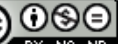

This work is licensed under a Creative Commons Attribution-NonCommercial-NoDerivatives 4.0 International (CC BY-NC-ND 4.0) License. 